\title{
The littoral: facing constraints, initiating dialogue, taking action
}

\author{
H. Flanquart • C. Meur-Férec • Ph. Deboudt • V. Morel • \\ A.-P. Hellequin • J. Longuépée
}

Received: 03 July 2009 /Revised: 03 July 2009 / Accepted: 04 July 2009 /Published online: 8 September 2009

(C) Springer Science + Business Media B.V. 2009

\section{Introduction}

This special issue of the Journal of Coastal Conservation: Planning and Management (JCCPM) is a compilation of contributions from the international multidisciplinary confer-

Tous les auteurs sont membres de la Maison Européenne des Sciences de l'Homme et de la Société, MESHS, USR, 3185, CNRS, Lille, France.

All the authors are members of the MESHS Maison Européenne des Sciences de l'Homme et de la Société, (European House of Human and Society Sciences), USR, 3185, CNRS, Lille, France.

H. Flanquart · A.-P. Hellequin

EA 4348, Institut des Mers du Nord,

Université du Littoral Côte d'Opale,

59140 Dunkerque, France

C. Meur-Férec $(\bowtie)$

Géomer, UMR 6554 CNRS LETG,

Institut Universitaire Européen de la Mer,

Université de Bretagne Occidentale,

Université Européenne de Bretagne, Plouzané, France

e-mail: meurferec@univ-brest.fr

P. Deboudt

EA 4019, Territoires, Villes, Environnement, Société, Université de Lille 1, 59655 Villeneuve d'Ascq cedex, France

e-mail: philippe.deboudt@univ-lille1.fr

\section{Morel}

EA 2468 DYRT

(Dynamiques des Réseaux et des Territoires)

Université d'Artois, en délégation à l'UMR 2724 IRD-CNRS

GEMI (Génétique \& Evolution des Maladies Infectieuses)

Centre IRD-Cayenne, Cayenne,

Guyane Française, France

e-mail: valerie.morel@univ-artois.fr

\section{J. Longuépée}

EA 4026, Centre d'Etudes et Recherches Economiques

et Interdisciplinaires de l'Artois,

Université d'Artois, Arras, France

e-mail: jlonguepee@free.fr ence: The Coastline: Facing constraints, initiating dialog, taking action, which was organized in Lille, France from January 15 to 18,2008 and brought together 230 participants. Our multidisciplinary team, composed of researchers ${ }^{1}$ specializing in the coastal zone, organized this event in partnership with the CNRS (National Center for Scientific Research) and three universities (Lille1, Littoral Côte d'Opale, and Artois). The conference was the result of around ten years of reflection on the issue of coastline conservation, particularly through combined coastal research projects ${ }^{2}$

The meeting was an original event in more ways than one.

Firstly, based on the theme, we wanted to shed light on the specificities of our coastal areas today through the words "facing constraints, dialogue and action". In certain respects, living along the coast or locating one's production activities there means facing constraints: coastal erosion, marine pollution, pollution from harbour activities, rising real-estate prices, urbanization, conflicting interests and so

\footnotetext{
${ }^{1}$ Organization Committee: Deboudt $\mathrm{Ph}$, Deldrève V, Flanquart $\mathrm{H}$, Hellequin A-P, Herbert V, Longuépée J, Meur-Férec C, Morel V, Petit O.

${ }^{2}$ Main national and regional combined programs conducted:

LITEAU—Dauvin et al. 2002, "Integrated management of coastal zones: tools and perspectives for the preservation of our natural heritage" Patrimoine Naturel, $n^{\circ}$ 57, National Museum of Natural History, Paris, 346 p.

PNEC-Meur-Férec et al. 2008. "The vulnerability of coastal territories: evaluation, stakes and public policies." Four unpublished reports

D2RT - Deboudt et al. 2008, "ECOlogical INequalities within the urban margins of the LITtOral territories" (INECOLITO), Final Report for the "Territorial policies and sustainable development" Program, MEDAD, PUCA, $529 \mathrm{p}$.

REACTION-Herbert V., Petit O. (coord), Beaurain Ch., Deboudt Ph., Deldrève V., Letombe G., Longuépée J., Masson E., Maillefert M., Meur-Férec C., Morel V., Zuindeau B. , "Environmental risk and collective action, applied to industrial risks and coastal erosion in the Pas de Calais region", Report, 122 p.
} 
on. Dealing with these constraints entails understanding, analyzing, organizing and above all, talking; dialogue in an attempt to share a vision of the coastal territory, the priorities to be put forth and the future to be planned for. Understanding and naming what the constraints and stakes are and analyzing them, means taking action; acting to defend one's own interests or those of the population for which one is responsible, so that future generations can benefit from all the amenities the coast has to offer.

This event was also original because of its format and the wealth of exchanges between the 230 participants from a large variety of disciplinary horizons, from geology to sociology, from biology to economics. And even if academics and researchers were in the majority, as is common in scientific events, the doors were wide open to all "practitioners" (technicians, association members, elected officials, etc.) confronted with the complexities of coastal systems on a daily basis and anxious to talk with scientists.

82 presentations made during the symposium were all accompanied by brief papers; they constitute the proceedings of this event, and are available for consultation on the MESHS $^{3}$ and the RFRC ${ }^{4}$ websites. The 9 articles presented in this issue of the Journal of Coastal Conservation Planning and Management were selected by a scientific committee, modified according to editorial and formatting requirements and submitted to international reviewers.

For the introductory article, our purpose is to analyze, from the body of the 82 presentations, the «building context» of the scientific production related to this international symposium, therefore enhancing possible interactions between the production of knowledge and those who produce it (Knafou 1997). As such, our goal is to understand the way in which coastline issues are understood within the scientific community, specifically in France: how does one break down the purpose of one's study? How does one conceive the collaboration with other disciplines, or with coastline managers to better grasp the coastal system, analyze it and propose concrete measures? All these questions, set before the presentations and publications, are not neutral: they could namely contribute to outlining the future for coastline research. They also lean on a certain number of paradigm forming (in the sense of Kuhn 1996) theoretical and methodological presuppositions. It is precisely this paradigmatic aspect that we propose to analyze.

\footnotetext{
${ }^{3}$ Maison Européenne des Sciences de l'Homme et de la Société, www.meshs.fr (European House of Human and Society Sciences)

${ }^{4}$ Réseau Français de Recherche Côtière (French Network of Coastal Research) (European ENCORA program), rubrique MédiaWiki, colloque littoral 2008: www.cetmef.equipement.gouv.fr/rfrc/liens_encora.php
}

\section{Looking at a multi-faceted event}

The composition of the scientific committees and the organization reveal the spirit of the symposium

The purpose of the symposium was to welcome all questioning, be it purely scientific or on the fringes of development-action, but always centered on this singular point: the littoral zone. The composition of the Organization Committee was the first indicator of the willingness to look at all questions linked to the coast in a non-exclusive manner. The committee, though comprised around a core grid of geographers (five out of nine), also included two sociologists and two economists, all of whom had lengthy experience in interdisciplinary work. The scientific committee, chosen by the Organisation Committee, was even more diversified, with six geographers, two jurists, an ecologist, two sociologists, two economists, a political analyst, an urban developer and a geologist, from five countries, belonging to thirteen universities, two State administrations, two major national research organisations (CNRS and Ifremer) and one European institution. These diverse disciplines and angles of observation in dealing with coastal issues (views from researchers, academicresearchers, coastal managers...) were both the main cause and guarantee of the diversity in the presentations.

Institutional and disciplinary plurality of the presentations chosen

Of the 130 summaries submitted in October 2007, 82 were selected by the scientific committee to be presented during the symposium. The institutional origins of the speakers were dominated by universities both French and foreign, which represented $78 \%$ of the speakers (respectively $50 \%$ and $28 \%$ ). $14 \%$ of them came from major French research organisations and $8 \%$ from research departments or associations (Fig. 1).

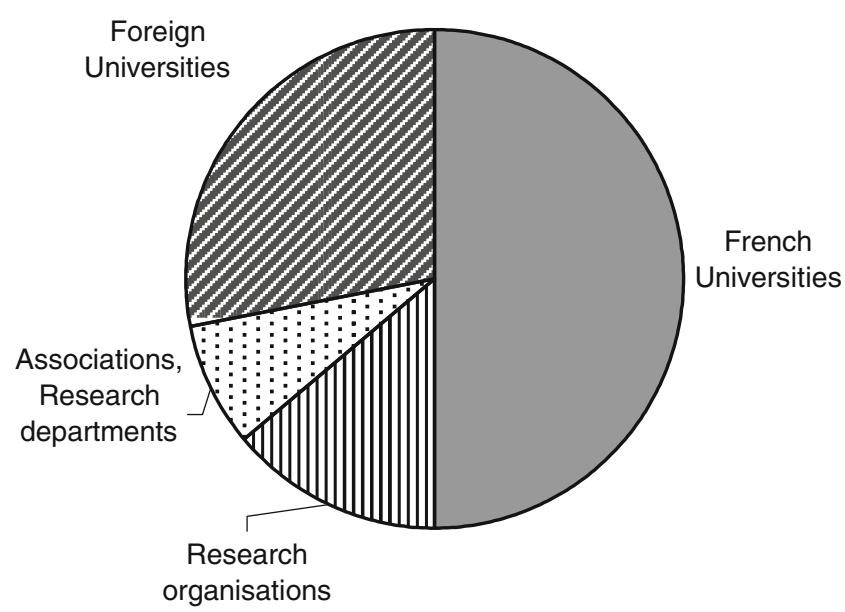

Fig. 1 Institutional origins of the 82 speakers 
The geographical origins of the speakers were very diverse, though dominated by France (81\%); numerous countries were nevertheless represented: Italy, Greece, Ireland, Great Britain, Belgium, Turkey, Germany, the United States, Canada, and several African countries. In total, Africa represented $8 \%$ of the speakers, Europe (excluding France) $7 \%$, North America 2\% and Asia 2\% (Fig. 2). This breakdown reveals two complementary rationales on the participation in an international symposium ${ }^{5}$ held in France. Firstly, language is a determining factor, because it allows for closer contacts between those participating; which would explain why the foreign participants came primarily from Quebec and French-speaking African countries. The second rationale is the geographical proximity of the symposium venue: when developing an international research project, the financial resources of the research teams do not necessarily allow for overseas travel.

Less collaboration between institutions and disciplines than expected

If we focus on the amount of joint work between authors to write the articles, first we notice that the Organisation Committee's preferred call for a multidisciplinary approach was partially heard: indeed we found joint presentations from researchers belonging to different disciplines, associating for example law and biology, economics and biology, anthropology and geography or even biology and geography. Ecologists appear to be the most present in multidisciplinary collaborations. Undeniably they occupied a pivotal position in a number of speeches presented. To a lesser degree, geography, with its dual physical and human aspect, often served as a "border escort" between the disciplines (Jollivet 1992).

As for institutional and geographical belonging, the associations of authors revealed few collaborative efforts between countries and research facilities of different types (American and Mexican universities for example; French, Swiss and Philippine universities; universities and national research organisations). Presentations associating researchers and coastal managers were even fewer. To what would appear as a certain apprehension, we can propose three explanations, not mutually exclusive from one another for that matter. First, science dissects the real into abstract objects, into fragmented problems entrusted to different disciplines, whereas a coastal manager must, under the control of government authorities, resolve a concrete problem requiring him/her to summarize knowledge produced by researchers from different scientific fields. Only a

\footnotetext{
${ }^{5}$ The call for presentations was edited in French and English and circulated on European (EUCC) and world (UGI) disciplinary and thematic networks. The scientific committee included foreign researchers.
}

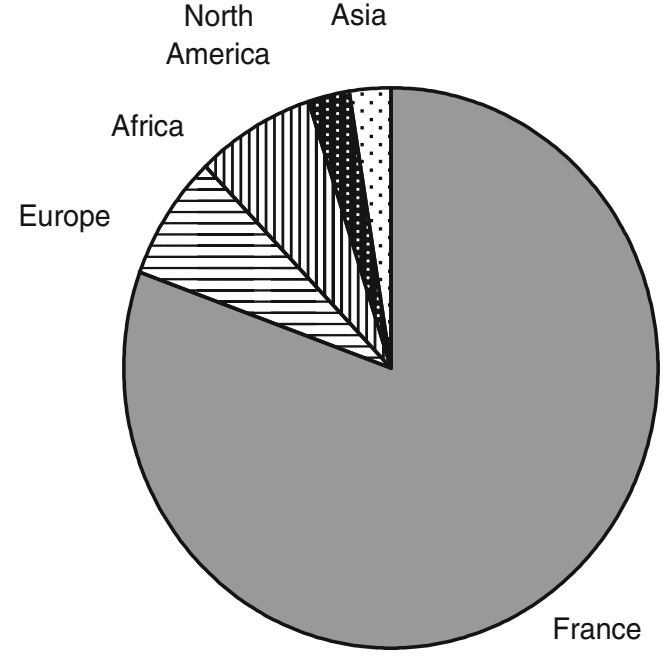

Fig. 2 Geographical origins of the 82 speakers

group of experts from different disciplines (hard and social sciences) can truly shed light on the public authority decision making process in the field of coastal management, as in many other areas; and it is very difficult to work out (Roqueplo 1997). Secondly, in both spheres - research and coastal management-, institutional recognition is not acquired in the same way. A researcher, subjected to the ever increasing pressure for scientific publications and the impact factor (especially since the appearance of the "Shanghai" classification), is not encouraged to conduct applied, let alone multidisciplinary research, which, by tradition, is less valued academically ${ }^{6}$. For his/her part, a coastal manager can have the tendency to be reticent, or at least show little interest in associating him/herself with researchers whose reflections often appear too theoretical or distanced from his/her preoccupations. The third explanation for these weak collaborations can be found in the fairly strong temporal dissociation between scientific work, which often requires a long investigative period, and political and technical intervention, subject to the necessity for action.

To these three main reasons, we can add a fourth to explain the compartmentalization of these two worlds: the few occasions presented for them to meet. Even though some initiatives have headed in this direction, for example the actions of the EUCC (European Union for Coastal Conservation), especially in the French branch, which systematically associates researchers and practitioners in the field, or certain networks encouraged by Europe like the ENCORA (European Network on Coastal Research), platforms for operational exchange are still rare.

\footnotetext{
${ }^{6}$ Applied research suffers from a lack of scientific recognition, especially in certain highly structured academic disciplines like economy and law (the case in France).
} 
Despite these obvious constraints, connecting the two worlds of research and management is necessary in our view because even if the practitioner must often "act in an uncertain world" (Callon et al. 2001), this action gains in durability if it is nourished with scientific knowledge, and research would gain in "public utility" by restoring itself in a societal context. This is one of the major stakes in Integrated Coastal Zone Management.

\section{The articles in this special issue: a glimpse at current coastal research}

We chose to present the articles for this special issue by dividing them into three thematic headings, even if we are aware that it could be somewhat arbitrary to form groups and trace boundaries this way. These three headings reflect three closely interlinked coastal dimensions: the natural littoral, dependent on very specific dynamics, the oecumenal littoral, inhabited and developed by man and the institutional littoral, governed by legislative and regulatory texts (Bousquet 1990).

\section{The natural littoral}

For this first heading geomorphological entries were favored. The first article analyzes what could be the setback line for the beaches in the Golfe $d u$ Lion (French Mediterranean) subjected to severe erosion. The article is the fruit of collaboration between academics, a research organisation and an expert from a research department; it focuses on a mathematical model to attempt a projection by the years of 2010-2030 (Sabatier et al. 2009).

The second text deals with the resistance of a portion of the coast in South Vietnam, following a strong man-made impact: the war and its associated high levels of dispersed defoliants. The authors analyze the rebirth of a mangrove landscape, highlighting in particular the capacity of this area not only to regenerate itself but also to attenuate the energy developed along the coasts during the passing of cyclones (Tran et al. 2009).

The third article studies the evolution of lagoon habitats in La Mancha (coast of Veracruz, Mexico) in relation to the variations in the flow of sediments in the Gulf of Mexico, notably by analyzing aerial photographs taken over the past 3 decades (Psuty et al. 2009).

The oecumena littoral

This second heading contains articles focusing in particular on the ways in which the coast is inhabited and visited and the resources utilized. Who are the inhabitants of and visitors to the coastal zone? How do they envision the coastline? What do they look for? Are they all welcome? The two selected articles attempt to answer these questions.

The first article focuses on pinpointing what the tourist attractiveness of the Côte d'Opale (North of France) is for the local, English, and Belgian-Flemish populations. Thanks to an investigative study conducted by means of a questionnaire the author compares the different national perceptions of this territory (Kuehn 2009).

The second article tackles the question of integrating stigmatized or marginalized populations within diverse tourism practices and how they are re provided for in tourism areas along the coastline of the Alpes Maritimes Côte d'Azur region. Interviews were conducted with the major actors of coastal resorts to evaluate the representation of and the provisions for the handicapped within tourism infrastructures. The image portrayed by handicapped tourists is in contradiction with that of the luxury tourism industry. If some effort has been made to welcome these tourists on special-needs sites (beaches with improved handicapped access), the integration of this population outside of the reserved areas remains questionable (Christofle et al. 2009).

The third article addresses the cohabitation of man and seabirds on protected natural sites: the former mainly occupies a fringe of the coast on a temporary and recreational basis whereas the latter has its survival at stake: nesting to perpetuate the species. And so we find ourselves within the boundaries of science and ethics; the analysis of two sources, an international bibliography on man-bird interactions and a series of interviews with the managers of protected species in Brittany (western France), allows us to better understand this issue (Le Corre 2009).

The fourth article, associating French, Swiss and Filipino geographers, focuses on coastline risk areas. It looks at the vulnerability of the Philippines' coastal populations to cyclones and proposes a vulnerability analysis model, which integrates data on the land-sea interface. The cross analysis of data reveals how people and goods are exposed to coastline hazards. This GIS (Geographic Information System) represents a tool for decision makers responsible for the prevention of risks and for territorial development planning (Gaillard et al. 2009).

\section{The institutional littoral}

The articles grouped into this third heading all characterize, directly or indirectly, public policies.

The first article adopts an essentially legal angle in analyzing the way in which the ICZM (Integrated Coastal Zone Management) system is put into place in Italy. Centralized government, showing little involvement with the issue, leaves it up to the regions to deal with the question, each in its own manner, at the risk of a lack of coherence (Rochette 2009). 
The second text, from a study of the Oder estuary (Baltic Sea, Germany), presents the issue of creating ICZM indicators on a regional scale. By cross analyzing a field approach (bottom-up) with an institutional approach (topdown), this article proposes integrating global and local indicators for the ICZM system (Hoffman 2009).

The question of the multifunctional aspects of the coastal zone and the ensuing conflicts arising from its use is at the center of the third article. From the example of the deteriorating coastal environment of the Laguedoc-Roussillon (south of France) region, the author looks at and analyzes the variability of the origins of conflicts, the nature of conflictual processes as well as the regulatory methods put into place to attempt to remedy them (Cadoret 2009).

The fourth text under this heading proposes a critical analysis of the European recommendations on the ICZM of 2002, applied to the problems of coastal erosion management. The authors, three Irish geographers, highlight the problems of contradictions and absence of a hierarchy between the eight principles put forth, of which some have a global reach (retreat strategy, long term reasoning) and others result from local considerations (protecting structures, short-term reasoning) (Mckenna et al. 2009).

Finally, the last article -written by three urban planners from two universities in Quebec and New-Brunswick in Canadaanalyzes the interactions of ICZM actors and particularly the role of concerted discussions in the local governance of a StLaurent estuary site (Guillemot et al. 2009).

\section{Prospects for multidisciplinary research in coastal areas}

The scientific exchanges during the symposium revealed the importance of multidisciplinary approaches in answering to the needs of coastal actors, but also to address the need for research to progress. Over the last ten years our team, among others, has been involved in building a multidisciplinary research approach (scientific production from several disciplines on the same subject) as well as an interdisciplinary approach (the production of summary knowledge organised from several disciplines) on coastal territories. The 2008 symposium allowed us not only to get one step further toward this goal, but also to give new life to projects already underway and to open new horizons for scientific collaboration.

Several major themes appeared to be harbingers for "multi-disciplinarity" in this field.

The problems for coastal territories to adapt to climate change - and especially to manage the risks of coastline movement (erosion and sea submersion), exacerbated by the accelerated sea level rise - necessitates dealing with the question of vulnerability from a global stand point (physical, economical, social, institutional...). And there- fore to associate in the same questioning many varied disciplines, such as geomorphology, geology, geography, economics, sociology, law, etc. in analyzing (even measuring) this vulnerability and proposing solutions.

Even if there is a large international consensus on the ICZM concept, its appropriation by all actors and its implementation still pose major difficulties. The questions concerning the "governance" of coastal zones still remain important research areas, especially in France where sharing competence between the State, local authorities and other territorial actors (professionals, associations) has yet to be stabilized. As such, geographers, sociologists and political scientists have all the more reason to work together in this vast field of research.

While remaining in the spirit of ICZM, integrating the three dimensions of sustainable development represents another prospect for multidisciplinary mobilization, particularly by taking into account the social dimensions which are often neglected when facing ecological and economical dimensions. Multidisciplinary research on ecological and environmental inequalities could contribute to this factor.

The subject of sea-land integration is another challenge for ICZM, i.e. the way to manage marine areas in coherence with land areas represents another difficult field open to potential research on different questions within the same system.

The management of sea pollution for example, must take into account rare events (oil slicks), as well as other more insidious types of pollution, like the illegal emptying of fuel tanks or the addition of runoff from catchment basins and ground-water. These different forms of pollution can damage the quality of coastal waters, create health problems, harm the aquaculture and fishing systems as well as tourism (green tides). These subjects are of particular concern to geographers, geologists, ecologists, chemists, but also to economists and legal practitioners.

Furthermore, the multiplicity of economic activities practiced at sea, especially close to the coasts (coastal seas), like the production of marine energies (offshore wind turbines, wave energy, etc.), the working of mineral deposits on continental shelves, fishing, aquaculture, maritime transportation and nautical tourism, makes the management and preservation of the sea more complex. As on land, but in a very different context (private property does not exist at sea, resources are split over three dimensions, etc.), these multiple activities create risks of conflicts in utilisation, difficulties in regulating and necessitate regulating practices to preserve the environment and marine resources. Regulation is in line with a strategic and spatial plan currently being developed. The European Union is significantly contributing to this plan, particularly through its managing directive "strategy for the marine 
environment" (2007) and its blue book for "an integrated maritime policy" (2007). In France, the creation of the Agence des Aires Marines Protégées (Agency for Protected Marine Areas) represents a first step in this area.

So the necessity to take the marine aspect of the coastline into account, and particularly regulating the utilisation of marine space, raises many questions that researchers-legal practitioners, geographers, economists, ecologists, etc.- can address.

Another major ICZM challenge is the integration of science and coastal management. Despite the difficulties highlighted in the previous section, these two spheresscientific and management-have everything to gain in multiplying exchanges and establishing close dialogues. Along with fundamental research, scientists can also develop projects answering to problems of society and be enriched by the experience of practioners out in the field; managers for their part, and beyond their daily preoccupations, can enlarge their spatial and temporal horizons by integrating advancements produced by researchers. And this dialogue will be facilitated if scientists manage to decompartmentalize their research questions by opening up to the notion of multi-disciplinarity, even inter-disciplinarity because only summary knowledge produced by researchers having mobilized different disciplines to analyze the same complex problem is truly useful for managers and political authorities (Roqueplo 1997). Different States and the European Union have a central role in this dialogue, particularly by taking the initiative to sponsor research programs targeted for multidisciplinary teams and systematically combining scientists and managers.

\section{Conclusion}

This symposium made it possible to take another step forward and to open perspectives, previously under-explored, for the scientific community working on coastlines; it demonstrated the relevance and fecundity of multidisciplinary reasoning, which strives for inter-disciplinarity, like the notion of a greater and more regular collaboration between coastal scientists and "practitioners". We are now becoming conscious of the necessity to develop discussion platforms and interdisciplinary networks, since studying the facts concerning the coastline can only be fully intelligible under the light of complexly integrated elements from nature and society, which are difficult to narrow down with a mono-disciplinary approach.

The major question raised throughout the symposium was on the process of intertwining the knowledge between the different possessors of this coastline expertise. How to make use of and build on knowledge and expertise, which remains too fragmented and insufficiently shared? Each discipline, according to its own interests, or even to the finances it has been granted, tries to respond to current questions posed by the scientific and political communities and the general public. Though the symposium gave prominence to cross-checking in questioning the issues, it also too often revealed the absence of bridges between scientific disciplines in trying to answer them, each participant perceiving his/her approach and the results obtained as his/her own acquired knowledge, his/her property.

This finding highlights the need for more innovative ways of questioning and applying new methods of analysis based on the implementation and recognition of new tools, which favor dialogue, horizontal and vertical integration. Forming networks of knowledge and defining coastline project territories could be an answer to a new organisation for research in coastal zone. (Morel et al. 2008).

\section{References}

Bousquet B (1990) Définition et identification du littoral contemporain. Rev Jurid Environ 4-1990:451-468

Cadoret A (2009) Conflict dynamics in coastal zones: a perspective using the example of Languedoc-Rousillon (France). J Coast Conservat. doi:10.1007/s11852-009-0048-9

Callon M, Lascoume P, Barthes Y (2001) Agir dans un monde incertain: essai sur la démocratie technique. Seuil, Paris

Christofle S, Massiera B, Denis Parisot D, Gay J-C (2009) The coastline, tourism and the handicapped: getting the French Riviera fit for more accessible tourism and seaside activities; the decisive role in facing stigmatization of the handicapped. J Coast Conservat (in press)

Dauvin J-C (coord), Bellan G, Bellan-Santini D, Capet Y, Deboudt Ph, Desroy N, Dewarumez J-M, Dubrulle J-B, Ghézali M, Guillaumont B, Le Pennec N, Lozachmeur O, Meur-Férec C, Ruz M-H, Mesnard A-H, Pouille X, Videment L (2002) Gestion intégrée des zones côtières: outils et perspectives pour la préservation du patrimoine naturel, Patrimoine Naturel, Muséum National d'Histoire Naturelle, Paris, 57, 346p

Deboudt $\mathrm{Ph}$, Deldrève V, Houillon V, Paris D (2008) Inégalités écologiques, inégalités sociales, et territoires littoraux : l'exemple du quartier du Chemin Vert à Boulogne-sur-Mer (Pas-de-Calais, France). Espace, Population, Société 2008-1:173-190

Gaillard J-C, Maceda EA, Stasiak E, Le Masson V, Le Berre I, Espaldon M-V (2009) Sustainable livelihoods and people's vulnerability in facing coastal hazards. J Coast Conservat. doi:10.1007/s11852-009-0054-y

Guillemot J, Plante S, Boisjoly J (2009) Participative governance and integrated coastal management: an experiment in dialogue in the insular community of Isle-aux-Coudres (Quebec, Canada)

Hoffmann J (2009) Indicators for an ICZM; experience with a problem-oriented approach. J Coast Conservat. doi:10.1007/ s11852-009-0052-0

Jollivet M (1992) Sciences de la nature, sciences de la société : les passeurs de frontière. CNRS edition

Knafou R (dir) (1997) L'état de la géographie. Paris, Editions Belin, $438 \mathrm{p}$

Kuehn C (2009) Representation of tourist interest in the Opal coast by local populations, English and Belgian-Flemish speaking populations. J Coast Conservat. doi:10.1007/s11852-009-0061-z 
Kuhn TS (1996) The structure of scientific revolutions. The University Chicago Press, Chicago

Le Corre N (2009) Bird disturbance on conservation sites in Brittany (France): the standpoint of geographers. J Coast Conservat. doi:10.1007/s11852-009-0057-8

Mckenna J, Cooper JA, O'hagan A (2009) Coastal erosion management and the European principles of ICZM: local versus strategic perspectives. J Coast Conservat. doi:10.1007/s11852008-0040-9

Meur-Férec C, Deboudt Ph, Morel V (2008) Coastal risks in france: an integrated method for evaluating vulnerability. J Coast Res $24: 178-189$

Morel V, Körfer A, Deboudt Ph (2008), Réseaux et Gestion Intégrée des Zones Côtières dans l'Union européenne: un regard de géographes, Vertigo, vol.8, http://www.vertigo.uqam.ca/vol8no1/ frame article.htlm
Psuty NP, Martínez M, López-Portillo J, Silveira TM, García-Franco JG, Rodríguez NA (2009) Interaction of alongshore sediment transport and habitat conditions at Laguna La Mancha, Veracruz, Mexico. J Coast Conservat. doi:10.1007/s11852-009-0060-0

Rochette J (2009) Challenge, dialogue, action: recent developments in the protection of coastal zones in Italy. J Coast Conservat. doi:10.1007/s11852-009-0051-1

Roqueplo P (1997) Entre savoir et décision, l'expertise scientifique. INRA, Paris

Sabatier F, Samat O, Brunel C, Heurtefeux H (2009) Determination of setback lines on eroding coasts. Example of the beaches in the Gulf of Lions (French Mediterranean Coast). J Coast Conservat. doi:10.1007/s11852-009-0062-y

Tran T, Amat J-P, Pirot F (2009) Landscapes of mangrove forests and littoral dynamics in the south viêt-nam. J Coast Conservat. doi:10.1007/s11852-009-0063-x 